Tim Pohlmann* and Knut Blind

\title{
The Interplay of Patents and Standards for Information and Communication Technologies
}

\begin{abstract}
ICT products are often interdependent and in some cases indispensably work together. Firms may thus compete on different market levels pursuing different business models to sponsor their proprietary technologies and to maintain market share for their products and services. Interoperability of products is a crucial factor for market success and firms evermore have to coordinate and set standards. These standardized technologies are in some cases protected by patents. Standard essential patents claim an invention that must be used by any company to comply with a technical standard. They are subject to a new and different legal framework which goes beyond the rights of regular patent law. This may influence incentives to develop and specify ICT standards, incentives to invest in R\&D or incentives to file patents. Yet, the inclusion of intellectual property in standards, and the strategic behavior of its owners, can have far-reaching consequences for market structure, market entry, and sustained technical progress and innovation. This article discusses current legal and economic issues on the interplay of patents and standards and provides empirical insides on licensing, patenting and coordination.
\end{abstract}

DOI 10.1515/pik-2014-0016

\section{Technology Standards and the Interplay with IPR}

In the past years discussions about the interplay of IPR (intellectual property rights) and technological standards have been increasing. On the one hand this is due to the growing importance of technological standards in our interconnected information and communication society, where interoperability and common agreement on a technology is crucial to unlock innovation [8]. On the other hand recent problems of IPR and standards such as patent

* Corresponding author: Tim Pohlmann:

E-Mail: tim.pohlmann@tu-berlin.de

Knut Blind: E-Mail: Knut.Blind@TU-Berlin.de hold-up ${ }^{1}$, patent ambush ${ }^{2}$ or royalty stacking ${ }^{3}$ behavior have caused expensive litigation cases and raised questions in patent law, contract law and especially in antitrust law ([24]; [14]; [19]). In the field of ICT (Information and Communication Technology), standards frame a large number of innovative technologies (WiFi, LTE, RFID, DVD, Bluetooth etc.). The need for interoperability comes with an increasing sophistication of technology standards. In this context, standard setting is much more demanding in terms of R\&D (research and development), representing a key strategic stake for companies that may increase the value of their patented technology by having it approved as part of an industry-wide standard. Patents that would necessarily be infringed by any implementation or adoption of a standard are called standard essential patents [26].

Although the need for interoperability is not recent, the last two decades have seen standard setting in ICT evolve from mere coordination of common specifications to the joint development of complex technology platforms [2]. As a consequence, the number of patents infringed by standards has been increasing dramatically over the same period [26], raising concerns about the rising cost of royalties for users of some ICT standards [25]. Besides the growing technical sophistication of standards, this trend is due to a use of patents for a broader set of strategic motives [7] and more aggressive patenting strategies of firms [6] who seek to derive revenue from their standard essential patents. Empirical evidence indeed suggests that standard essential patents are more valuable than other patents [22] and that

1 Patent hold-up is a situation in which a patent holder commits on licensing standard essential patents to FRAND terms, a standard developing organization relies on that promise and uses the patented technology to set a standard, but the patent holder subsequently breaches that promise and denies to license or demands higher license fees than promised.

2 A patent ambush occurs when a patent holder withholds information on standard essentiality during the participation in standard setting activities and subsequently asserts that the unknown essential patent is infringed by use of the standard as adopted.

3 Royalty stacking refers to situations in which a single standard potentially infringes on many patents. The standard adopter thus has to pay royalties to all patent holders resulting in a cumulative license like a stack of royalties. 
firms which own a large share of essential patents also enjoy a strong position in the market for standard-compliant products [5]. Furthermore recent empirical research has provided evidence that standard essential patents may directly increase a company's financial returns [21].

Especially in the context of patent thickets ${ }^{4}$, empirical studies evidence an excessive patent filing behavior for certain technologies. The assumption is that companies try to protect their inventions with a preferably high number of patents. The increasing complexity of patent files may cause coordination problems and in some cases even leads to litigation [25].

\section{Standards Setting for ICT and Antitrust Concerns}

Technological standards often shape widely used technologies. UMTS and LTE ensure communication of mobile phones and smart phones. The Wi-Fi standard provides a wireless connection to local internet hosts. CDs and DVDs guarantee that decoders or players read discs and project movies onto TV screens and the MP3 standards allows us to listen to high quality music in compressed data formats. Most consumers are not aware that these standards incorporate hundreds of patents from multiple companies. Only in recent years famous litigation cases (Qualcomm v. Broadcom; Infineon v. Rambus; IP COM v. Nokia; Apple v. Samsung; etc.) drew attention to the often complex legal questions concerning standard setting and the role of IPR. Authorities of competition policy are concerned with standardization practices in terms of the direct coordination among competing companies that work together on a commonly agreed technology. One main antitrust issue is the open participation and appropriate technology selection [28] which addresses the legal necessity of the participation of Standard Setting Organizations (SSOs). Even though standard setting is very costly in terms of personnel and travel expenses [22] and thus usually only attracts big or medium sized firms, formal standards organizations are by law and policy open to all interested parties. ${ }^{5}$ Another antitrust concern is the appropriate standard selection. Since antitrust

4 Patent thickets refer to a situation in which a large number of patent claims overlap like a dense web.

5 Informal standards consortia sometimes request high member fees or only allow participation by invitation. However these practices to not apply for international standards organizations such as ISO, IEC, CEN, ITU, ETSI or IEEE. authorities themselves often lack technical expertise, this is difficult to evaluate. One can argue though, that the appropriate standard is selected when all affected stakeholders in the market agree to the standard [28]. The selection procedures of standard proposals always request consensus decisions, while majority voting is usually not accepted. ${ }^{6}$ However, some industry standards may not be set by formal standard organizations but by rather informal fora and consortia. ${ }^{7}$ Standards consortia may have differing policies and standardization procedures, which are less inclusive in terms of membership and require less consensus in terms of decision making [1].

The most discussed issue that became relevant for antitrust questions in the last decades is the role of patents that are essential to a standard. The fear is that essential patents may leverage market power and lead to exclusive effects [19]. Whereas patents are actually intended to allow their owners to exclude others from using the protected invention, the main objective of standards is to encourage the spread and wide implementation of the standardized technology [16]. Manufacturers that create products are not able to bypass standards or invent around standardized technologies, since standards shape the interface to connect, communicate or work on or with other products and platforms. A smart phone without UMTS or LTE adoption, for example, would not be able to connect to any network. A patent that blocks a standard could thus also block a whole technology or even whole industries [17]. This apparent conflict is resolved by licensing. Standardization participants are expected to allow others the use of their technology, but they can demand adequate royalties. SSOs often mandatorily require firms participating in standard setting to disclose any patent that might turn out to be essential for the standard in question. Furthermore holders of such patents have to submit a declaration whether they accept to commit to fair, reasonable and non-discriminatory terms of licensing for these patents (FRAND commitments). If a firm discloses a patent and refuses to commit to such licensing terms, the SSO will usually set the standard excluding the IPR protected technology. In a recent survey companies state that securing freedom to operate and market entry are the most important reasons for owning standard essential patents (figure 1).

Even though standardization may be accompanied by complex licensing agreements, the rules for the licensing of

6 Find details in the ISO guidelines under http://www.iso.org/iso/ guidance_liaison-organizations.pdf.

7 Standards consortia are rather informal groups of entities with the goal of setting standards or agreeing on a common specification. Well known standards consortia are the W3C or the IETF. 


\section{Securing freedom to operate / reducing risk of being accused of infringing}

Signalling own technological competencies

Entering into cross-licensing agreements / increasing bargaining power in licensing negotiations (e.g. for lowering or eliminating license fees)

\author{
Influencing technological trajectory or standards \\ competition
} Joining patent pools / increase bargaining position in
patent pools

Generating licensing revenue

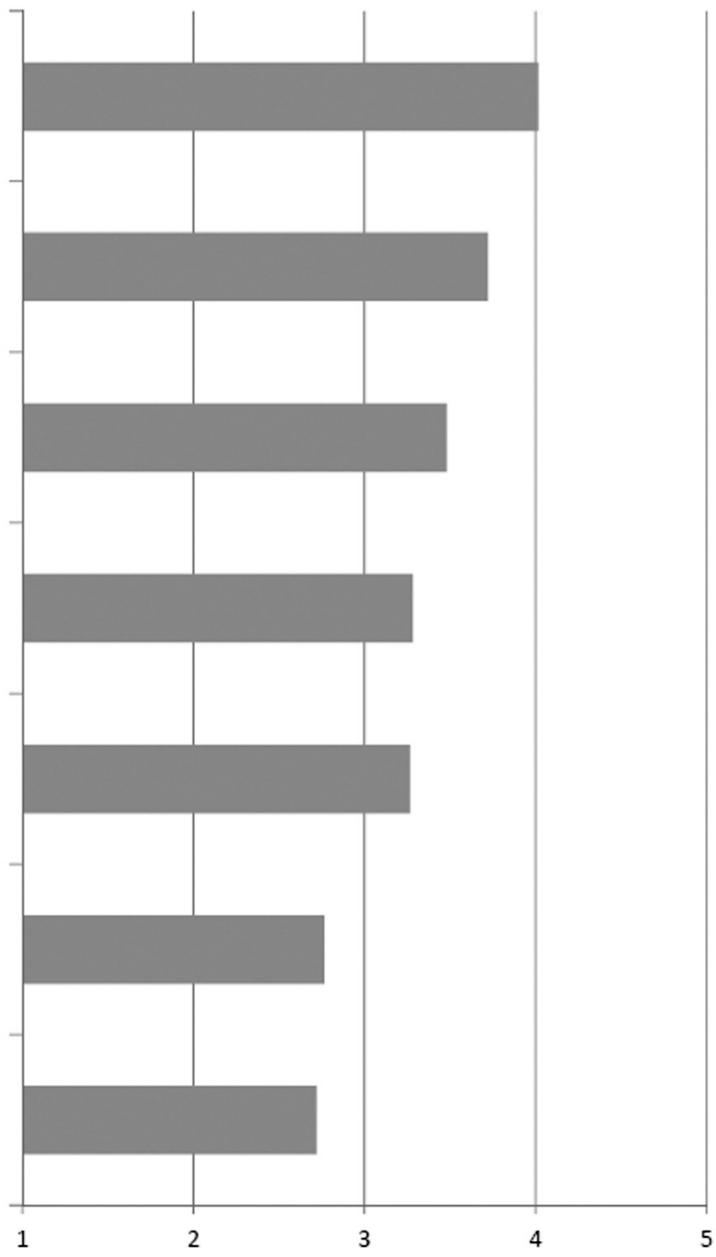

Essential IPR owner

Figure 1: Reasons why companies want to own standard essential patents. ${ }^{8}$

patents essential for a commonly agreed standard are often unclear and can be subject to complex discussions. Especially companies that do not own standard essential patents fear that these patents may slow down standardization, block consensus decision-making and decrease standard adoption (figure 2). Nevertheless, FRAND commitments are commonly seen as an important instrument to curb abusive strategies. Moreover, antitrust authorities have referred to FRAND commitments as a remedy to the potential competitive risks of standardization ([15]; [11]; [27]; [23]).

8 Blind et al.,EU Commission, 2011, S.1-213, http://ec.europa.eu/ enterprise/policies/european-standards/files/standards_policy/iprworkshop/ipr_study_final_report_en.pdf

\section{FRAND Commitments and Antitrust Policy}

Antitrust law interprets the licensing of essential patents as a market of its own. A company that owns an essential patent holds a dominant position in this market. The standard adopter has the right to get a license under FRAND terms, which can be raised as a defense in infringement cases. An important body of academic research interprets FRAND commitments as restricting the maximum height of royalty requests and devotes little attention to examining whether pricing is non-discriminatory among the licensees. This general line of interpretation is not really acceptable for antitrust scholars, since competition policy, especially if dealing with patents, should not aim at restricting profits, but at guaranteeing a level playing field for competition [4]. 


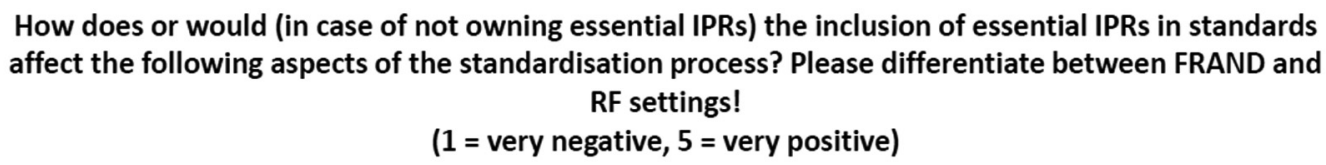

The inclusion of attractive technologies (high performance, cost saving, etc.)

Number of non producing entities (providing technology, but not producing goods) involved in standardisation processes

Number of potential implementors participating in the standardisation processes

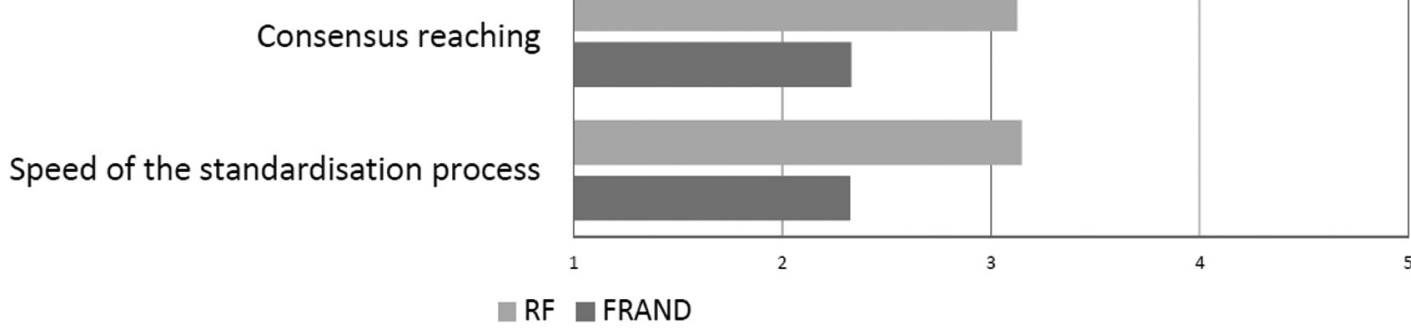

Figure 2: How standard essential patents may affect standard setting. ${ }^{9}$

Diverging interpretations of FRAND commitments are a frequent source of conflict. Very important cases of alleged breach of FRAND commitments have motivated debates intended to give a concrete meaning especially to the terms "fair" and "reasonable". The question is how much weight the patented technology has compared to other parts that frame the standard or product. Especially when several companies hold patents for a specific standard and the licensing contracts are not transparent, the problem of double marginalization may arise. In these situations every patentee would overestimate the value of its own essential IPR and the costs of a cumulative license would not be "fair" and "reasonable" anymore [18]. As shown in figure 3, royalties may indeed result in remarkable percentages, increasing in rates by standard generation.

Many complaints about anticompetitive effects of standardization and cases of antitrust litigation focus on the structure of pricing, i.e. on claims that specific licensing schemes put some licensees at a competitive disadvantage with respect to their direct competitors. In several industries, especially in the consumer electronics and mobile telephony sectors, respectively, holders of essential

9 Blind et al, EU Commission, 2011, S.1-213, http://ec.europa.eu/ enterprise/policies/european-standards/files/standards_policy/iprworkshop/ipr_study_final_report_en.pdf. patents compete on the production market against producers who do not hold patents. The argument is that patent holders profit from standardization using cross licensing or joined licensing schemes to exclude their downstream market competitors ([15]; [23]).

\section{Patent Pools, Joint Licensing}

Antitrust authorities have in some cases softened their approach to far-reaching business coordination among patent owners inside and outside standard setting bodies. The favorable business reviews for the MPEGLA patent pool by the US Department of Justice and the EC in 1997 set an example for joint licensing models. Most negotiations on joint licensing take place outside standard setting bodies several years after the release of the standard. While SSO bylaws require a disclosure of any essential IPR, SSOs are not responsible for these practices being followed correctly. However, during the last years standard setting bodies no longer refrain from dealing actively with intellectual property issues. ${ }^{10}$ For example the Eur-

10 The US Department of Justice and the Federal Trade Commission announced in their 2007 Report, Antitrust Enforcement and Intellectual Property Rights: Promoting Innovation and Competition, that they will review joint negotiation policies at standard setting bodies 
GSM, no cross licensing

GSM, cross licensing

GSM/UMTS, no cross licensing

GSM/UMTS, cross licensing

LTE(only), no cross licensing

LTE (only), cross licensing

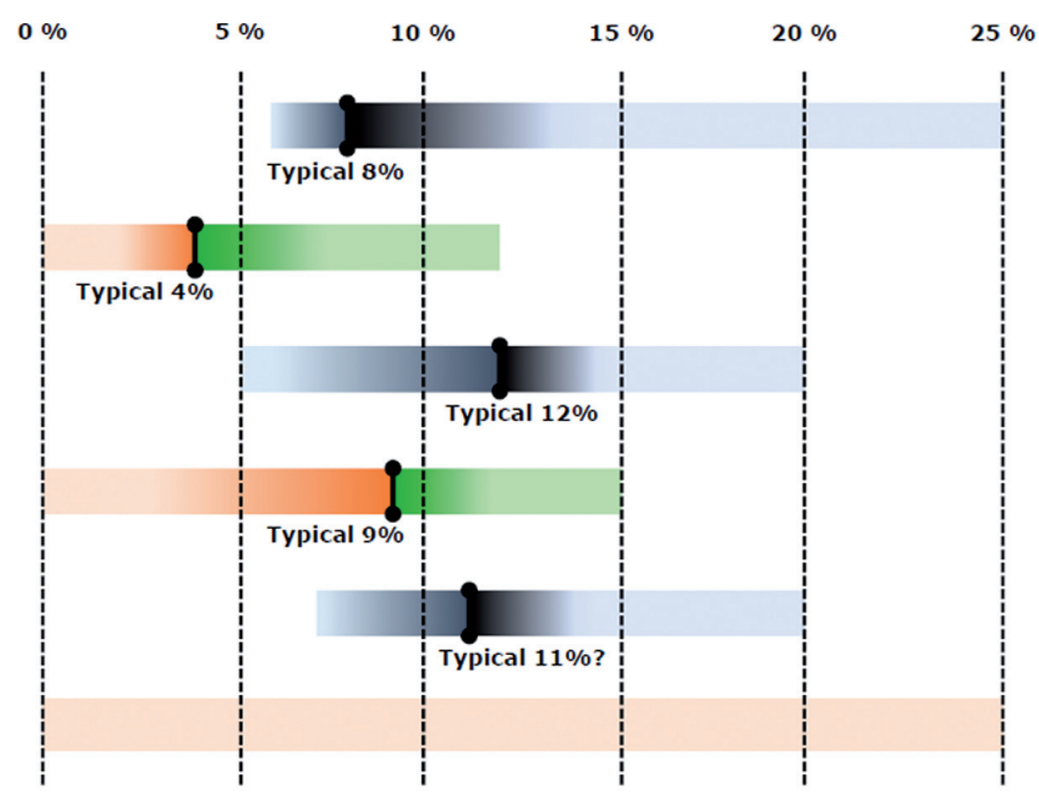

Figure 3: How standard essential patents may affect standard setting. ${ }^{11}$

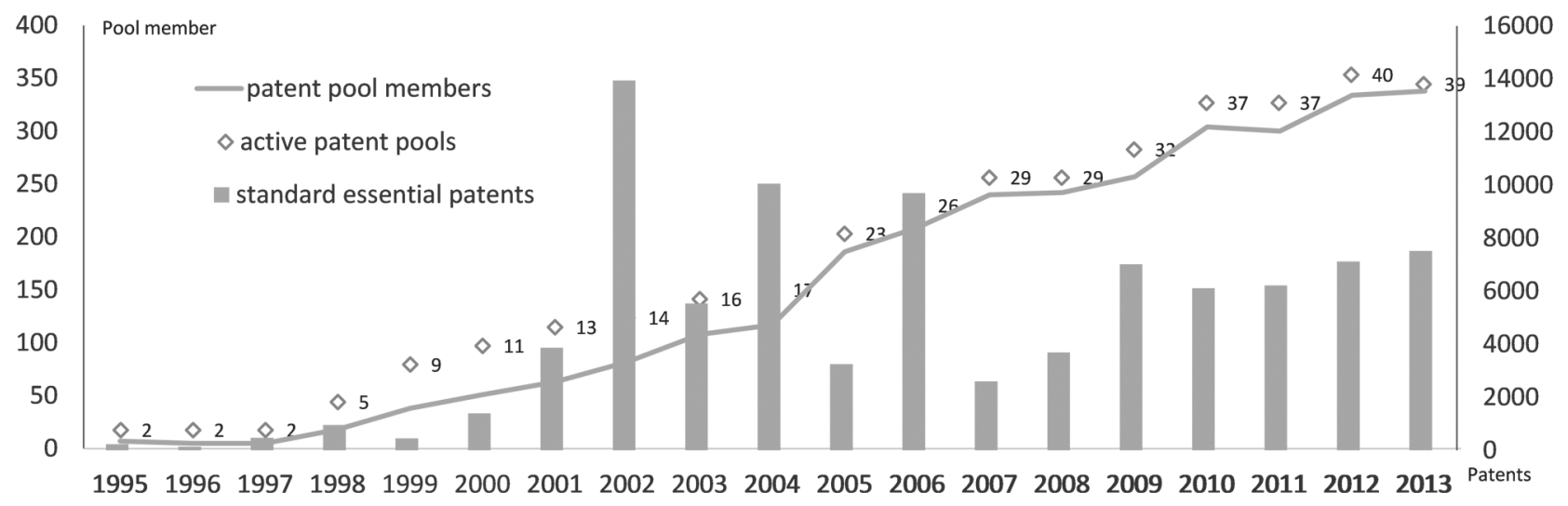

Figure 4: active patent pools, pool members and standard essential patent files over time $\mathrm{e}^{12}$

opean Digital Video Broadcasting (DVB) project of the European Telecommunications Standards Institute (ETSI) has a policy of actively promoting the creation of patent pools, at least one of which is managed by ETSI itself. The Institute of Electrical and Electronics Engineers (IEEE) has signed a general partnership agreement with the patent

under a rule of reason, rather than as per se illegal. Under: http:// www.ftc.gov/reports/innovation/P040101PromotingInnovationandCompetitionrpt0704.pdf

11 Blind et al.,EU Commission, 2011, S.1-213, http://ec.europa.eu/ enterprise/policies/european-standards/files/standards_policy/iprworkshop/ipr_study_final_report_en.pdf.

12 [3], the data was provided by IPlytics $\mathrm{GmbH}$ (www.iplytics.com). pool manager Via Licensing that should help foster rapid and smooth patent pool creation [13]. Figure 4 shows the increasing number of standard related patent pools and increasing pool memberships.

\section{Ex-Ante Licensing}

Another source of problems for competition policy is that standards are set before the precise licensing terms for essential patents are disclosed. An often-discussed solution would be that standard setting participants disclose explicit commitments before a standard is released. Since FRAND is not precise enough on the exact licensing 
amount, licensees fear excessive royalties after a standard is widely accepted in the industry. Especially in the field of ICT, companies and organizations urge to implement ex ante commitments of licensing terms, meaning that companies have to explicitly state their licensing conditions before the standard is set. This early commitment would increase the transparency of licensing and royalty stacking and hold-up strategies [12]. There is a strong asymmetry between the costs of choosing a different standard proposal and not implementing a generally accepted market standard [28].

\section{Discussion}

The current discussions show that the interplay between patents and standards still causes legal uncertainties for many companies. On the one hand, products must implement certain standards so that innovative solutions work together as part of a cross-system interoperability. On the other hand, it is often unclear for manufacturers who holds patents relevant for a standard and which royalties will be claimed. Especially for small and medium-sized enterprises or new market entrants it is often not transparent which patents are infringed when using standardized technologies. Furthermore, the growing trade of these patents also increases the complexity of identifying possible licensors [10]. These uncertainties increase the risk of investment in research and development activities and in the long term could reduce innovation investments of some manufacturers. There is also the growing fear of excessive royalties paid to non-manufacturing companies that hold patents and enforce them aggressively [20]. However, there are first initiatives to identify all patents relevant for technology standards, with the aim of creating more transparency in the market. ${ }^{13}$

Nevertheless, current disputes show that also patent holders have concerns regarding the interaction between patents and standards. If a patent is declared essential for a certain standard, the right to impose an injunction for infringement of these patents is limited in some cases. These are cases in which a licensee agrees to enter a licensing negotiation with the patent holder. However, licensees may delay the actual license payments over several years of negotiations, or even start litigation on invalidity.

13 In addition to a bilateral cooperation between the European $\mathrm{Pa}$ tent Office and several standard setting organizations, the initiative Open Patents and Standards Platform has collected information about thousands of patents that are essential for technology standards. More information at: www.iplytics.com.
Patent holders complain that the constraint on temporary injunctions takes away the leverage against non-paying patent infringers that are delaying the payment. This behavior is often referred to as reversed hold-up. On the other hand licensees argue that the possibility to impose an injunction could increase royalties even in the absence of a court decision. This is especially true when an injunction is used to thread patent infringers to speed up the payment of royalty fees. These fees would then be subject to an anticompetitive price [9].

To decrease legal uncertainty for standard adopters in the future, there is a need to further clarify FRAND statutes of the respective standards organizations. It appears, however, that they avoid such legal issues. Standards organizations state to merely provide a platform on which the parties concerned can resolve any discrepancies regarding the licensing of standard essential patents. Another aim should be a harmonization between the statutes of the respective standards organizations. Throughout the last years commercial entities and standards organizations have also initiated alternative patent licensing methods such as ex-ante royalty caps or royalty-free arrangements. Here, the DVB Forum, the Bluetooth Special Interest Group and the $\mathrm{W} 3 \mathrm{C}$ consortium are examples of new approaches that regulate the licensing of standard essential patents. There is also a tendency of large manufacturers like e.g. Apple, Cisco, Google and Microsoft to state so-called unilateral promises of a FRAND licensing to promote a transparency and reduce legal uncertainty.

\section{References}

1 Baron, J., Ménière, Y. Pohlmann, T. (2014): Standards, Consortia and Innovation, International Journal of Industrial Organization, in Press, DOI: 10.1016/j.ijindorg.2014.05.004.

2 Baron, J., Pohlmann, T. (2013): Who Cooperates in Standards Consortia: Rivals or Complementors?, Journal of Competition Law and Economics, 9 (4), pp. 905-929.

3 Baron, J.; Pohlmann, T. (2013): Patent Pools and Patent Inflation, cerna working paper.

4 Baumol William J.,Swanson Daniel G. (2005): Reasonable and Nondiscriminatory (RAND) Royalties, Standards Selection, and Control of Market Power, 73 ANTITRUST L.J. 1, 13.

5 Bekkers, R., Duysters G., Verspagen B. (2001): Intellectual prop erty rights, strategic technology agreements and market structure The case of GSM, Research Policy 31 (2002) 1141-1161.

6 Blind, K.; Thumm, N. (2004): Interdependencies between Intellectual Property Protection and Standardisation Strategies, in: Research Policy 33, 2004, S. 1583-1598.

7 Blind, K.; Edler, J.; Frietsch, R.; Schmoch, U. (2006): Motives to patent: empirical evidence from Germany, in: Research Policy, 35(5), 2006, pp. 655-672. 
8 Blind, K., Egyedi, T. (2008): The Dynamics of Standards, Edward Elgar Publishing.Chiao, B., Lerner, J. and Tirole, J. (2007), The rules of standard-setting organizations: an empirical analysis. The RAND Journal of Economics, 38: 905-930.

9 Blind, K., Pohlmann, T. (2013): Trends In The Interplay Of IPR And Standards, FRAND Commitments And SEP Litigation, les Nouvelles, pages 177-181, September 2013.

10 Bourreau, M., Ménièrey, Y., Pohlmann, T. (2014): The Market for Standard Essential Patents, cerna working paper.

11 Farrell, Joseph; Hayes, John; Shapiro, Carl; Sullivan, Theresa (2007): Standard Setting, Patents, and Hold-Up; 74 Antitrust L.J. 603.

12 Geradin, Damien (2006): Standardization and Technological Innovation: Some Reflections on Ex-ante Licensing, FRAND, and the Proper Means to Reward Innovators TILEC Discussion Paper No. 2006-017.

13 Gilbert, Richard J. (2004): Antitrust for Patent Pools: A Century of Policy Evolution, Stanford Technology Law Review 2004.

14 Hovenkamp, H. J. (2008): Patent Continuations, Patent Deception, and Standard Setting: the Rambus and Broadcom decisions, working paper.

15 Layne-Farrar, Anne; Padilla, A. Jorge; Schmalensee, Richard (2007): Pricing Patents for Licensing in Standard-Setting Organizations: Making Sense of Fraud Commitments; 74 Antitrust Law Journal 671.

16 Lemley, M. A. (2002). Intellectual Property Rights and Standard Setting Organizations. University of California, Berkeley School of Law, Berkeley.

17 Lemley, Mark A.; Shapiro, Carl (2007) Patent Holdup and Royalty Stacking; 85 Tex. L. Rev. 1991.

18 Lerner J, Tirole J. (2004): Efficient Patent Pools. American Economic Review 2004; 94; 691-711.

19 Lévêque Francois, Ménière Yann (2008): Technology Standards, Patents, and Antitrust; Competition and Regulation in Network Industries, Volume 9,No.1.

20 Pohlmann, T., Opitz, M. (2013): Typology of the Patent Troll Business, R\&D Management, Volume 43, Issue 2, pages 103-120, March 2013.

21 Pohlmann, T., Neuhäusler, P., Blind, K. (2014): Standard Essential Patents to Boost Financial Returns, R\&D Management, forthcoming.

22 Rysman, M., Simcoe, T. (2008) Patents and the Performance of Voluntary Standard Setting Organizations. Management Science, 54, 1920-1934.
23 Rysman, Marc, Simcoe, Timothy (2011): A NAASTy alternative to RAND pricing commitments, Telecommunications Policy, Volume 35, Issue 11, December 2011, Pages 1010-1017.

24 Shapiro, C. (2000): Setting compatibility standards: cooperation or collusion? In: Cooper Dreyfuss R, Leenheer Zimmerman DL, First $\mathrm{H}$ (Hrsg) Expanding the bounds of intellectual property. University Press, Oxford, S 81-101.

25 Shapiro, C. (2001). Navigating the Patent Thicket: Cross Licences, Patents Pools, and Standard Setting. In A. Jaffe, J. Lerner et S. Stern (Ed.), Innovation Policy and the Economy, Vol 1, MIT Press.

26 Simcoe, T. (2007): Explaining the Increase in Intellectual Property Disclosure. Pages $260\{295$ in Standards Edge: The Golden Mean. Bolin Group.

27 Schmalensee, Richard (2009): STANDARD-SETTING, INNOVATION SPECIALISTS AND COMPETITION POLICY. The Journal of Industrial Economics, 57: 526-552.

28 Teece, David J.; Sherry, Edward F (2003): Standards Setting and Antitrust Symposium: The Interface between Intellectual Property Law and Antitrust Law.

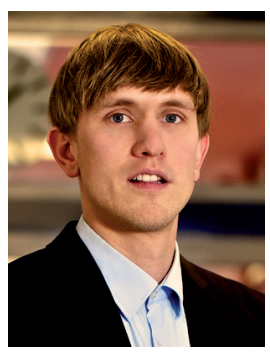

Tim Pohlmann: IPlytics GmbH Berlin, Chair of Innovation Economics, Technical University of Berlin

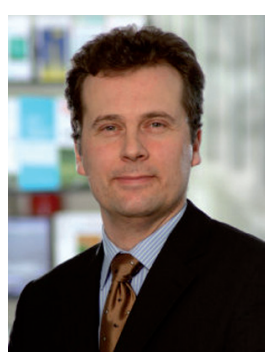

Knut Blind: Chair of Innovation Economics, Technical University of Berlin, Fraunhofer Institute for Open Communication Systems FOKUS 